Pobrane z czasopisma Annales $\mathrm{H}$ - Oeconomia http://oeconomia.annales.umcs.pl

Data: 26/04/2023 09:45:58

DOI:10.17951/h.2019.53.2.17-24

\begin{tabular}{lcc}
\hline \multicolumn{1}{c}{ A N N A L E S } \\
UNIVERSITATIS MARIAE CURIE-SKŁODOWSKA \\
LUBLIN - POLONIA \\
VOL. LIII, 2 \\
\hline
\end{tabular}

\author{
ALEKSANDRA DEWICKA \\ aleksandra.dewicka@put.poznan.pl \\ Poznan University of Technology, Faculty of Engineering and Management, \\ ul. Strzelecka 11, 60-965 Poznan, Poland \\ ORCID ID: https://orcid.org/0000-0001-8238-6602 \\ MICHAŁ TRZISZKA \\ michal.trziszka@put.poznan.pl \\ Poznan University of Technology, Faculty of Engineering and Management, \\ ul. Strzelecka 11, 60-965 Poznan, Poland \\ ORCID ID: https://orcid.org/0000-0003-0170-5849 \\ JOANNA ZIOMEK \\ joanna.ziomek@put.poznan.pl \\ Poznan University of Technology, Faculty of Engineering and Management, \\ ul. Strzelecka 11, 60-965 Poznan, Poland \\ ORCID ID: https://orcid.org/0000-0002-4063-6463
}

\title{
The CRM system and its role in raising the competitiveness of enterprises
}

Keywords: CRM; competition; entrepreneurship; customer relations

JEL: M15; M31; O32

How to quote this paper: Dewicka, A., Trziszka, M., \& Ziomek, J. (2019). The CRM system and its role in raising the competitiveness of enterprises. Annales Universitatis Mariae Curie-Sklodowska, sectio H-Oeconomia, Vol. 53, No. 2. 


\begin{abstract}
The globalisation of countries' economies and the growth of the market in the West are becoming important factors determining the activity of enterprises. In this changing economic environment, the search for new sources of concurrency advantage often determines the survival and development of an enterprise. Knowledge about the market, speed of decisions, innovations and customer relationship management (CRM) are becoming some of the key success factors. Following an analysis of the literature, this article presents the essence and definition as well as the benefits of CRM in terms of raising the competitiveness of enterprises for which the client plays a leading role.
\end{abstract}

\title{
Introduction
}

In today's economic outlook, the client plays a key role in the operations of enterprises, and all company activities should be carried out in such a way as to maintain the best possible relationship with the company. Competition for the customer and the pattern of general competition, as well as the modern globalisation of the economy, have become important factors conditioning the operations of enterprises.

In the dynamics of the changing economic environment, the search for new sources of concurrency advantage often determines the survival and development of business entities, and the broad knowledge of the market and the speed of decisions, as well as innovation and management, become some of the key success factors (Zając, 2007).

One of those factors is the customer relationship management (CRM) strategy, which assumes that the source of enterprise growth is, first, the proper nurturing of the relationship with the client and the consumer, who is increasingly aware of the advantages and disadvantages of the products and services offered. In the $21^{\text {st }}$ century, the strategy of individual contact with the client has become important, therefore, this study uses the literature and the available results of market research to present the essence of CRM in terms of raising the competitiveness of business entities.

\section{CRM system}

When describing the CRM system it should be remembered that it is primarily a business philosophy in which the client plays a leading role, and second, it is an analytical and IT system. CRM is now a common element of marketing for modern business enterprises. It is used in all business entities who value maintaining a stable relationship with clients. The idea of the CRM system is to connect two entities - the enterprise and the client - and this relationship brings mutual financial and business benefits.

CRM is a business strategy based on selecting and managing clients to optimise long-term benefits. It requires the introduction of a customer-oriented philosophy and business culture that ensures effective marketing, sales and service processes. 
Online CRM applications provide the opportunity to effectively manage customer contacts, leading to the superiority of this approach over the overall culture and strategy in the enterprise (Grzanka, 2009).

The strategy and implementation of the CRM system requires that enterprises use appropriate resources and knowledge, thus, there are many definitions of CRM. According to Tiwana, the CRM system is a process of managing relations with current clients in order to maintain them, maximise their loyalty and increase their revenues, and at the same time selectively attract new customers. According to other researchers, the CRM system creates a culture of improving the functioning of the company in terms of maintaining and developing relationships with clients. The adopted CRM strategy focuses on supporting marketing activities, the sales process and all activities related to customer service by directing attention only to the needs of the consumer, with a particular emphasis on culturally-developed behaviour patterns (Tiwana, 2003).

In the opinion of the system researchers, CRM extends the definition and concept of sales from a conscious act to a continuous process, covering all employees of a given economic entity. CRM defines each client by means of continuous acquisition and the appropriate use of available loyalty information. On the basis of another theory, the CRM system is aimed at improving and implementing such action strategies which, supported by modern technological solutions, reduce the discrepancy between the current and future activities of the organisation in terms of maintaining and acquiring new customers.

CRM is a modern management model, the measure of which is the best way to meet consumer needs. The goal of this approach is to develop internal and external relations with the consumer, which will directly increase the profit and productivity of the company. The relationships sought arise as a result of the use of technological solutions, strategic planning methods, and any other marketing and organisational improvement tools and techniques.

CRM applies to all aspects of management that meet individual customer needs, as well as improving their life cycle in the company. CRM is a relatively new approach in the field of management that integrates sales, order fulfilment and service offerings while coordinating all components of the interaction process with the consumer. The CRM system also finds its definition in IT. It covers the methods, software and other IT possibilities that enable the company to organise its relations with consumers in an orderly manner (Grzanka, 2009).

CRM is not only a tool but also a strategy for business philosophy, for which constant contact and customer retention is a key value. An important issue of the CRM system is to ensure the uniform operation in all business processes of the enterprise, starting from statistics and ending with the portfolio of offered goods and services.

There are several aspects and concepts and modules for CRM, but the most important are: 
- to ensure the entities of the economy are focused on the selected group of clients;

- to ensure suppliers and recipients collaborate to relate agreed and shared intentions;

- to use sophisticated technology to individualise contacts;

- to increase the operational efficiency of premises;

- to establish long-term cooperation with clients;

- to individualise direct contacts with clients;

- to ensure the basis for the company's operation is the satisfaction of the client and guarantee of his loyalty.

There are many other definitions and aspects of the CRM system that are encapsulated in various classification and communication models.

\section{Classification of CRM systems}

The literature review indicates the studies that have previously dealt with similar research topics before and their results. The literature background shows the results of the prior studies. Additionally, different options and perspectives from the literature can be identified and documented.

CRM enjoys considerable interest among business entities. The essence of the system, according to the definitions quoted, is the client, who should be approached individually in order to build his loyalty and sense of exclusiveness. The main areas of the concept of effective CRM include:

- estimating the potential value of the client;

- the management of advertising campaigns;

- acquiring and obtaining clients;

- risk reduction and management;

- systems supporting customer communication channels;

- integrated call centre systems;

- using the Internet in cooperation with clients (Grzanka, 2009).

Based on its application, the CRM system is divided into three important elements. The first of these is the communication element (interaction), responsible for communication with the client. The task of communication is to handle all possible customer contact channels with the organisation and ensure the independence of the customer service standard from the information and communication channel. Another element of the CRM system is the operating panel responsible for the automation of basic business processes such as marketing, sales and service. This involves collecting and sharing all possible information about the client, which enable its comprehensive and full service. The operating panel includes three groups of functionalities, targeted at marketing, sales and technical support (Januszewski, 2018). The last element of the CRM system is the analytical function, responsible 
for analysing customer behaviour, on the basis of data collected in the operating system. Its main task in the CRM system is to perform a comprehensive analysis and processing of customer data.

The typical functional features of the CRM system are constant contact with the client from the first meeting and building a permanent relationship to solving the problem, as well as:

- automatic routing of orders to other people so that the client feels that an appropriate employee is assigned to them;

- shortening working time and facilitating work for employees;

- generating automatic contracts between a client and an enterprise;

- efficient electronic communication between the company and the client;

- reporting tools that help highlight the most common problems related to customer service, learn about the customers' needs and evaluate service performance;

- the CRM system primarily has a mail merge feature, which is sent to potential and existing customers, thus, reducing the scope of work of enterprises (Zając, 2007).

All this is possible thanks to three modules. The sales module that automates the sales process. The result of this process is the automatic collection of details of the information that is the subject of the transaction. However, for the transaction to take place, it is necessary to perform a number of elementary activities which can be included as standard: the recognition of customers' needs, submitting an offer and in some cases its presentation, negotiating a contract, collecting orders, preparing invoices, sending goods, and settling the supplies of sold goods and services (Dembińska-Cyran et al., 2004). Sales functions, due to the thematic and technological scope, can be divided into the following sub-functions: customer records (companies, natural persons), records of contact persons, sales planning and forecasting, sales records, and sales analysis.

Another module is marketing, which includes the scope of automation of activities related to the comprehensive registration of standard marketing activities. Detailed sub-functions implemented in the marketing function are primarily: the registration of advertising campaigns carried out, handling of correspondence received from customers, telemarketing (telesales), market segmentation and the monitoring of competition, as well as a marketing encyclopaedia.

The last module of the CRM system is service and after-sales service, which is similar to the sales module to a certain extent. It is related to the warranty and post-warranty service for sold products, goods and services. The importance of this module lies in showing special interest to the customer who has already bought something in the company. This action, referred to as an after-sales service, includes: examining the degree of customer satisfaction, obtaining information from customers about the assessment of the purchased product and service, testing preferences, opinions and further needs, and encouraging you to make further purchases in this company (Rudawska, 2008). 
All this is possible thanks to the use of appropriate and tailored CRM communication channels suited to the preferences of users and consumers.

\section{CRM communication channels}

From the technical and communication side, CRM systems consist of application server layers, a database server and interface layers. The most important element of CRM is communication, which helps to create client-enterprise relations. There are many forms of media that offer the most effective and efficient communication with the client. Currently, most CRM systems use communication modules with the client via SMS, web page, e-mail and call centre (Wilde, 2011).

The task of an SMS text message is to provide information about products and contests, as well as preventive information about payment dates. A similar role is played by e-mail, which, via an automated e-mail, enables the mass sending of data for marketing or information purposes to a selected group of recipients.

Web pages enable the displaying of presentations and maps of the client's visits to the website to determine his preferences and needs, while the call centre module enables the identification of the caller, the receiving of information about the history of cooperation or contacts, and many more functions.

There are many other means of communication, however, it is important that selected communication channels enable efficient communication with the client and bring tangible benefits for the business strategy.

\section{CRM benefits}

The main recipients of CRM solutions include enterprises and organisations that are characterised by having a large number of clients. These are primarily: large corporations and retail chains, telecommunications companies, suppliers of computer hardware and software, manufacturers of complex systems, companies in the fast-moving consumer goods industry, pharmaceutical companies, banks, insurance companies, pension funds, real estate offices, and clients in health care and education, as well as state administration.

All these business entities gain many benefits from running a CRM system, both in terms of measurable and non-measurable values. First, users highlight the advantages of CRM including the availability of information at any time, shortening the time of preparing offers, knowledge about customers, relief from routine work and increasing customer satisfaction, as well as saving time.

The most important benefit as enjoyed by $83 \%$ (Internet data) of entrepreneurs who have implemented this strategy to their entities is the increase in revenues and profits per one client. CRM software allows you to develop a plan to increase your 
sales and profits in the long term, by making sales data or forecasts available immediately. CRM enables policy makers to closely examine revenue and costs, and this helps determine the necessary discounts or rebates (Wereda, 2009).

CRM introduces a change of strategy towards the customer, thanks to which the response time to the customer is shortened, with the possibility of extending the time spent with the client. This efficient and effective communication allows new business contacts to be established, as well as existing links to be improved. Enterprises thus increase their sales and revenues by generating more potential customers. Thanks to the automation found in the CRM system, it is possible to monitor contacts with customers, as well as to create twisted sales areas.

The need of each company is to gain a competitive advantage that can be created by finding a niche in the market and satisfying market needs, which allows flexibility due to scalability. The scalability of the CRM system plays a particularly important role in the functioning of business entities that want to expand the number of clients in the near future. Many CRM solutions, such as SalesPro CRM, or licensed software on a computer, help companies integrate all their business solutions while reducing the amount of time that is required to solve administrative and office matters.

CRM, introducing significant changes in the marketing activities of enterprises, streamlines the service of the target customer, as confirmed by $91 \%$ (Internet data) of business entities. The CRM software includes centralised customer data with which you can quickly contact the customer via an e-mail template. CRM stores customer data through sales points and purchase data. Another benefit of running CRM in enterprises is increased cross-selling and expanded sales for new and existing customers. It has become clear to companies that in financial terms it is important not only to acquire new customers but, above all, ensure the loyalty of existing ones. CRM creates a list of valuable clients from call centres, databases and other sources, allowing customer service employees or sellers to make an extended offer to their clients (Wereda, 2009).

CRM includes a competitor and customer tracking function. The management and sales department can access these reports to identify trends, forecast and track the sales process, and evaluate their business results. CRM software regulates the availability of information that facilitates key decisions and also contains many important article and pamphlet resources. CRM profiles customers by conducting better target marketing. The CRM system captures customer details such as pending orders, payment histories and items purchased, the region from which the customer comes and many more. CRM centralises databases that are used to profile clients, as well as predicts what services a customer may need in the future.

The general benefits for the business entities operating the CRM system are the ongoing control of the quality of customer service, the full and current analysis of the effectiveness of marketing and commercial activities, and, above all, access to the real knowledge base about the surrounding economic market (Januszewski, 2018). 


\section{Conclusions}

The CRM strategy requires changes in a company, primarily in its organisational and marketing culture. CRM brings many benefits, such as establishing and maintaining contacts with clients; a centralised, constantly updated and available data warehouse; the creation of an IT system that processes opinions, comments, complaints, inquiries and customer requests; improving sales and customer relations; better informing sellers and employees of the department customer service; the possibility of shortening the sales cycle; reducing information chaos and consolidating the knowledge of employees about customers; the possibility of improving the quality of services; and, above all, increasing the chance for clients to appreciate the service's professionalism (Porębska-Miąc, 2010).

In the CRM hierarchy, the client is placed first, and the strategy focuses on supporting all activities aimed at the consumer's needs, with a particular emphasis on the culturally-developed patterns and behaviours necessary to survive in today's competitive and economic market.

\section{References}

Grzanka, I. (2009). Kapitat społeczny w relacjach z klientami. CRM a społeczny potencjat przedsiębiorstwa. Warszawa: CeDeWu.

Dembińska-Cyran, I., Hołub-Iwan, J., \& Perenc, J. (2004). Zarządzanie relacjami z klientem. Warszawa: Difin.

Januszewski, J. (2018). Funkcjonalność informatycznych systemów zarządzania, t. 1: Zintegrowane systemy transakcyjne. Warszawa: Wydawnictwo Naukowe PWN.

Porębska-Miąc, T. (2010). Rola technologii, procesów i ludzi w sukcesie strategii CRM. In: T. Porębska-Miąc, H. Sroka (red.), Systemy Wspomagania Organizacji SWO 2010. Katowice: Wydawnictwo AE.

Rudawska, E. (2008). Znaczenie relacji z klientami w procesie ksztaltowania wartości przedsiębiorstwa. Szczecin: Wydawnictwo Naukowe Uniwersytetu Szczecińskiego.

Tiwana, A. (2003). Przewodnik po zarządzaniu wiedza e-biznes i zastosowania CRM. Warszawa: Placet.

Wereda, W. (2009). Zarządzanie relacjami z klientem (CRM) a postępowanie nabywców na rynku ustug. Warszawa: Difin.

Wilde, S. (2011). Improving Customer Relationship Through Knowledge Application. New York: Springer. Zając, P. (2007). CRM Zarzadzanie relacjami z klientem w logistyce dystrybucji. Wrocław: Oficyna Wydawnicza Politechniki Wrocławskiej. 